\title{
Analisis Potensi Likuefaksi dan Perbaikan Tanah dengan Stone Column: Studi Kasus pada Coal Shelter PLTU Lontar, Banten
}

\author{
Yuli Fajarwati ${ }^{\mathrm{a}^{*}}$, Rama Indera Kusuma ${ }^{\mathrm{b}}$

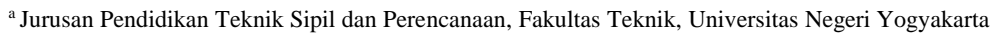 \\ b Jurusan Teknik Sipil, Fakultas Teknik, Universitas Sultan Ageng Tirtayasa
}

Keywords:

Liquefaction

Soil improvement

Stone column

\begin{abstract}
The high demand for electricity needs requires the availability of new generation sites. The new plant developed is a PLTU in Lontar. The condition of coal shelter as a research site dominated by silty clay and silty sand and located in the earthquake zoning is high that the planning of the coal shelter area must accordance with the feasibility of building establishment, it is necessary to analyze the potential liquefaction and improvement methods. Soil improvement efforts to reduce the potential for liquefaction include soil improvement with stone columns. The method of liquefaction analysis in this study uses the method developed by Idriss and Boulanger. The results of the analysis of the potential for liquefaction at BH-1 occurred at a depth of 3-16 m and at BH-3 the potential for liquefaction occurred at a depth of 4-24 m. Potential of the thickest layer for liquefaction is at BH-3 with a depth of $24 \mathrm{~m}$. Improvement with a stone column can reduce the potential for liquefaction and can increase the value of the safety factor against the potential for liquefaction at the coal shelter location. Improvement analysis with a stone column using Plaxis software, the value of the safe factor after installing the stone column at BH-1 FS 2.89, at BH-3 FS became 2.65.
\end{abstract}

\begin{abstract}
ABSTRAK
Banyaknya permintaan kebutuhan listrik yang tinggi diperlukan ketersediaan lokasi pembangkit baru. Pembangkit baru yang dikembangkan yaitu PLTU Batubara di Lontar. Kondisi coal shelter sebagai lokasi penelitian yang didominasi oleh lapisan tanah lempung kelanauan dan pasir kelanauan serta berada pada zonasi gempa cukup tinggi sehingga perencanaan area coal shelter harus memenuhi syarat kelayakan pendirian bangunan, maka perlu dilakukan analisis potensi likuefaksi serta metode perbaikannya. Upaya perbaikan tanah untuk mengurangi potensi likuefaksi yaitu perbaikan tanah dengan stone column (kolom batu). Metode analisis likuefaksi pada penelitian ini menggunakan metode yang dikembangkan oleh Idriss dan Boulanger. Hasil analisis potensi likuefaksi pada titik BH-1 terjadi di kedalaman 3$16 \mathrm{~m}$ dan pada titik BH-3 potensi likuefaksi terjadi pada kedalaman 4-24 m. Lapisan yang paling tebal mengalami potensi likuefaksi ada pada titik BH-3 dengan kedalaman $24 \mathrm{~m}$. Perbaikan dengan stone column dapat mengurangi potensi likuefaksi dan mampu meningkatkan nilai faktor keamanan terhadap potensi likuefaksi di lokasi coal shelter. Analisis perbaikian dengan stone column menggunakan software Plaxis, nilai faktor aman setelah dipasang stone column pada titik BH-1 FS 2,89, pada titik BH-3 FS menjadi 2,65.
\end{abstract}

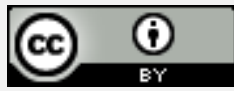

This is an open access article under the CC-BY license.

\section{Pendahuluan}

Indonesia merupakan negara dengan perkembangan listrik yang cukup tinggi. Dalam rangka memenuhi kebutuhan listrik di beberapa daerah, PT PLN merencanakan untuk membangun pembangkit yang baru. Dengan banyaknya permintaan kebutuhan listrik yang tinggi diperlukan ketersediaan lokasi pembangkit baru. Pembangkit baru yang dikembangkan yaitu PLTU Batubara. Salah satu PLTU Batubara yang sedang dikembangkan yaitu PLTU Lontar yang ada di wilayah Tangerang dengan kapasitas 3 $\times 315$ MW. Dengan adanya proyek pembangunan PLTU

*Corresponding author.

E-mail: yulifajarwati@uny.ac.id 
Batubara ini sehingga perlu direncanakan fasilitas coal shelter yang sesuai.

Area coal shelter di PLTU Lontar digunakan sebagai lokasi studi kasus dalam penelitian. Kondisi lokasi penelitian yang didominasi oleh lapisan tanah lempung kelanauan dan pasir kelanauan serta berada pada zonasi gempa cukup tinggi sehingga perencanaan area coal shelter harus memenuhi syarat kelayakan pendirian bangunan, maka perlu dilakukan analisis potensi likuefaksi serta metode perbaikannya.

Likuefaksi merupakan proses terjadinya rongga antar partikel akan terisi oleh air dan kuat geser tanah turun menjadi nol yang mengakibatkan terjadinya gempa bumi. Kuat geser tanah yang menurun akan menyebabkan tanah mencair dan tidak akan dapat mendukung beban yang berada di atas permukaan. Ketahanan terhadap likuefaksi akan meningkat seiring dengan turunnya tingkat kejenuhan tanah. Tingkat kejenuhan tanah yang rendah dapat terlikuefaksi di bawah durasi waktu gempa yang lama. Persyaratan terjadinya likuefaksi umumnya terjadi pada uniform sand, loose sand dan jenuh air, dan nilai SPT kurang dari 15.

Gempa bumi dapat mengakibatkan terjadinya potensi likuefaksi yang berdampak terhadap kerusakan sarana dan prasarana infrastruktur [1]. Likuefaksi merupakan menurunnya kekuatan geser tanah yang disebabkan oleh beban seismik saat terjadinya gempa bumi (percepatan gempa lebih dari 0,25 g), saat tekanan air tanah naik maka tegangan efektif berkurang [2-3].

Faktor yang mempengaruhi terjadinya likuefaksi dapat berupa guncangan gempa bumi yang cukup kuat sehingga mampu merusak susunan butir tanah, tanah berpasir (loose sand), tanah jenuh air (saturated soil), dan muka air tanah dangkal [4]. Ciri tanah yang memiliki kerentanan terhadap likuefaksi yaitu dominan berupa tanah berpasir, tanah tidak padat dan jenuh air, memiliki muka air tanah dangkal.

Upaya perbaikan tanah untuk mengurangi potensi likuefaksi yaitu perbaikan tanah dengan stone column (kolom batu). Stone column merupakan salah satu metode perbaikan tanah yang dapat meningkatkan daya dukung tanah, mengurangi penurunan struktur yang dibangun di atasnya, meningkatkan kekuatan, menurunkan kompresibilitas pada tanah bergradasi halus, mempercepat konsolidasi dan mengurangi potensi likuefaksi tanah [5].

\section{Metode}

Studi kasus dilakukan pada Proyek Coal Shelter PLTU Lontar (lihat Gambar 1). Dalam menganalisis besarnya penurunan dan potensi likuefaksi diperlukan parameterparameter yang jelas berupa data tanah. Data yang digunakan adalah hasil pengujian lapangan dan laboratorium.

Metode analisis likuefaksi yaitu dengan menetapkan besarnya peak ground acceleration, menentukan magnitudo gempa, analisis likuefaksi dari nilai N-SPT dengan konsep cyclic stress [4] dan potensi likuefaksi dengan metode Liquefaction Potential Index [6-7]. Hasil akhir dari analisis ini adalah nilai $S F$ tiap lapisan tanah yang ditinjau dan grafik LPI. Analisis potensi likuefaksi dengan metode LPI dapat memberikan nilai besaran momen yang berbeda [8].

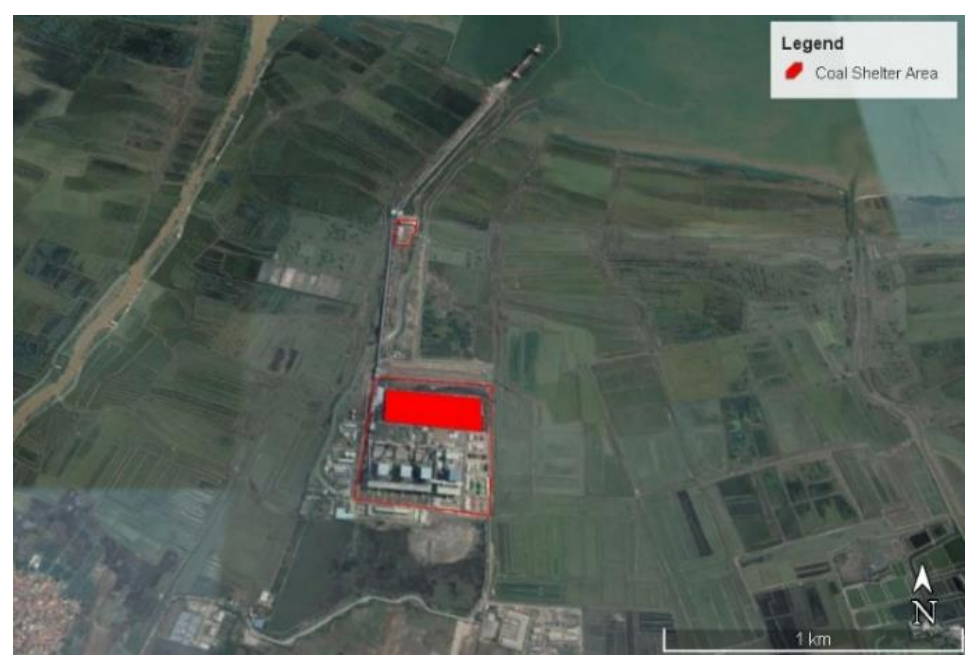

Gambar 1. Lokasi penelitian 
Analisis likuefaksi mengadopsi metode pendekatan yang dikembangkan oleh Idriss dan Boulanger. Metode ini dapat dilakukan karena memiliki pendekatan yang paling sesuai dengan terjadinya likuefaksi di lapangan [9].

Momen magnitudo gempa $\left(\mathrm{M}_{\mathrm{w}}\right)$ merupakan beban siklik yang dialami tanah, data $\mathrm{M}_{\mathrm{w}}$ diperlukan dalam analisa potensi likuefaksi [10]. Penelitian ini menggunakan data dari Peta Gempa Indonesia 2016 (lihat Gambar 2) dengan data Megathrust Jawa yaitu $\mathrm{M}_{\mathrm{w}}: 8,1$.
Data peak ground acceleration (PGA) diambil dari peta gerak seismik yang mengacu pada peraturan Peta Gempa Indonesia, nilai kelas situs tanah dan $P G A$ diambil dari puskim.pu.go.id. Nilai peak ground acceleration (PGA) pada lokasi coal shelter yaitu $0,36 \mathrm{~g}$.

Cyclic Stress Ratio (CSR) merupakan tegangan siklik gempa, untuk menentukan nilai koreksi tegangan akibat gempa. Seed dan Idriss telah menjabarkan formula tegangan siklik gempa [4] seperti Persamaan (1).

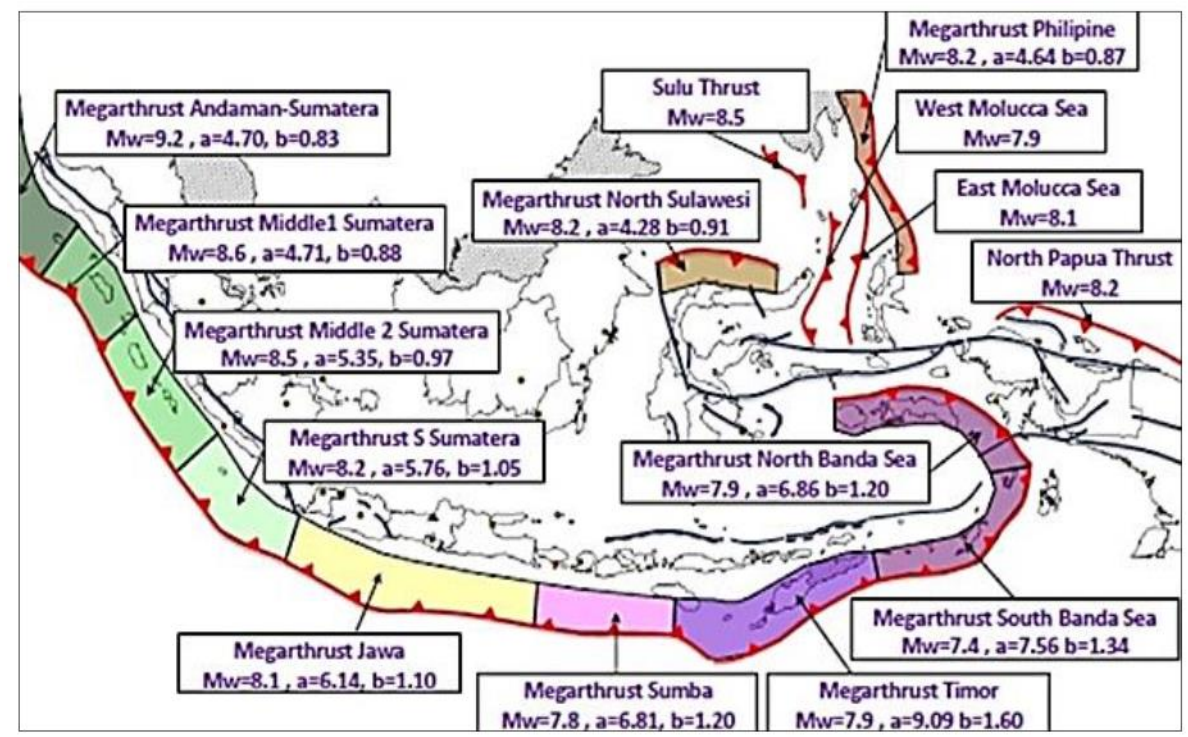

Gambar 2. Peta gempa Indonesia (diakses dari https://www.bmkg.go.id)

$$
C S R=0,65 \times\left(\frac{a_{\max }}{g}\right)\left(\frac{\sigma_{v c}}{\sigma_{v c}^{\prime}}\right) \times r_{d}
$$

Dengan $a_{\text {max }}$ : peak horizontal acceleration $(g), g$ : percepatan gravitasi $\left(9,81 \mathrm{~m} / \mathrm{s}^{2}\right), \sigma_{v o}$ dan $\sigma^{\prime}{ }_{v o}$ : total dan tegangan efektif overburden $\left(\mathrm{kN} / \mathrm{m}^{2}\right), r_{d}$ : koefisien reduksi tegangan pada suatu kedalaman.

Cyclic Resistance Ratio (CRR) adalah parameter ketahanan tanah untuk menahan beban siklik dari CSR. Nilai $C R R$ [11] dinyatakan pada Persamaan (2).

$$
C R R=C R R_{M 7,5} \times M S F
$$

Untuk mencari MSF menggunakan Persamaan (3).

$$
M S F=6,9 \exp \left(\frac{-M}{4}\right)-0,058
$$

$$
C R R_{M 7,5}=\exp \left(\begin{array}{l}
\frac{\left(N_{1}\right)_{60 c s}}{14,1}+\left(\frac{\left(N_{1}\right)_{60 c s}}{126}\right)^{2}-\left(\frac{\left(N_{1}\right)_{60 c s}}{23,6}\right)^{3} \\
+\left(\frac{\left(N_{1}\right)_{60 c s}}{25,4}\right)^{4}-28
\end{array}\right)
$$

Untuk menghitung nilai SPT terkoreksi menggunakan Persamaan (5).

$$
\left(\mathrm{N}_{1}\right)_{60}=N_{\text {value }} \cdot C_{N} \cdot C_{E} \cdot C_{B} \cdot C_{R} \cdot C_{S}
$$

Liquefaction Potensional Index (LPI) merupakan nilai indeks untuk mengetahui potensi suatu daerah terhadap risiko likuefaksi.

$$
L P I=\int_{0}^{20} f \times w . z
$$

dengan,

$f=1-S F$ untuk $S F=1$

$f=0$ untuk $S F>1$

$w z=10-0,5 z$

$z=$ kedalaman tanah tinjauan $(\mathrm{m})$ 
Tabel 1. Indeks potensi likuefaksi [7]

\begin{tabular}{cc}
\hline LPI & Potensi likuefaksi \\
\hline 0 & Sangat rendah \\
$0-5$ & Rendah \\
$5-15$ & Tinggi \\
$>16$ & Sangat tinggi \\
\hline
\end{tabular}

Factor of safety likuefaksi $\left(F S_{\text {Liq }}\right)$ adalah faktor aman terhadap likuefaksi. Apabila $F S_{L i q}<1$ menunjukkan terjadinya likuefaksi, sedangkan $F S_{\text {Liq }}>1$ aman dari potensi likuefaksi.

$$
F S_{l i q}=\frac{C R R_{M 7,5}}{C S R}
$$

Stone column terbagi menjadi 2 tipe, yaitu fixed type improvement dan floating type improvement. Fixed type improvement, ujung bawah stone column menempel pada lapisan tanah keras. Floating type improvement, ujung stone column berada di antara lapisan tanah lunak. Diameter stone column yang diprasyaratkan berkisar antara 0,5-1,0 m, dengan material pengisi berupa gravel atau coarse agregat dengan ukuran yang bekisar $40 \mathrm{~mm}$ [12]. Pola pemasangan stone column ada pola segitiga dan persegi. Dari segi keefektifan lebih efektif menggunakan pola segitiga. Dalam konstruksi pelaksanaannya pola segi empat lebih mudah pemasangan di lapangan sedangkan pola segitiga lebih stabil dan seragam penurunan tanahnya.

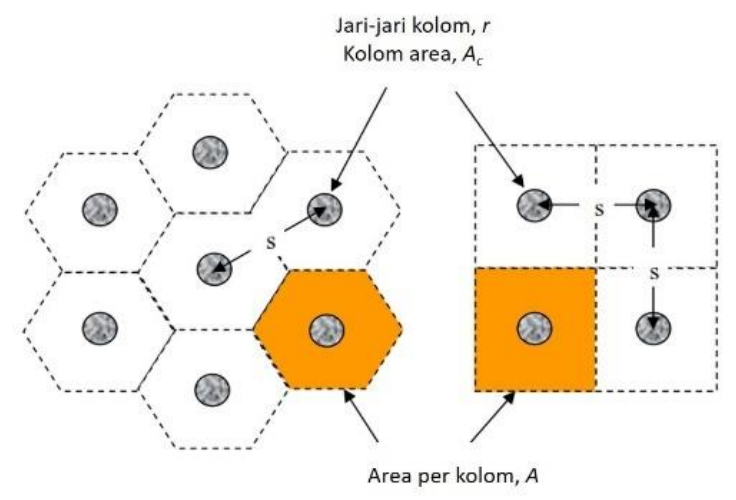

Gambar 3. Pola pemasangan stone column [13]

\section{Hasil dan Pembahasan}

\subsection{Karakteristik Tanah}

Pada penelitian ini digunakan data SPT (Standard Penetration Test) dan hasil uji laboratorium. Dalam melakukan interpretasi lapisan tanah, dibutuhkan data minimal 2 titik bor sehingga dapat diketahui ketebalan masing-masing lapisan tanah. Dalam penelitian ini digunakan 2 titik bor SPT dengan kedalaman $32 \mathrm{~m}$. Secara umum, lapisan tanah pada lokasi coal shelter menunjukkan bahwa sebagian besar lapisan berupa tanah lempung lanau. Dari hasil pengujian dapat dilihat bahwa lapisan tanah didominasi oleh beberapa jenis tanah lempung dengan ketebalan cukup besar, lapisan tanah pasir ditemukan pada kedalaman tertentu. Potensi likuefaksi dianalisis menggunakan data bor yang disesuaikan dengan lokasi segmen coal shelter yang ditinjau.

\subsection{Analisis Potensi Likuefaksi}

Dari hasil analisis data SPT (lihat Error! Reference source not found.) dan parameter-parameter pendukung lain, dihitung nilai faktor aman terhadap likuefaksi $\left(F S_{\text {Liq }}\right)$ yaitu perbandingan nilai Cyclic Resistance Ratio berdasarkan kekuatan gempa yang ditinjau $\left(M_{7,5}=8,1\right)$ dengan nilai tegangan siklik gempa $(C S R)$. Setelah diperoleh nilai faktor aman terhadap likuefaksi, kemudian diklasifikasikan untuk nilai $F S_{\text {Liq }}<1$ maka area tersebut berpotensi likuefaksi atau terlikuefalsi $(L)$ apabila nilai $F S_{L i q}>1$ area tersebut nonlikuefaksi $(N L)$. Rekapitulasi hasil perhitungan likuefaksi pada dua titik bore hole dapat dilihat pada

Tabel 2 dan Tabel 3.

Dari hasil uji SPT, lapisan tanah pada lokasi coal shelter sebagian besar lapisan berupa tanah lempung lanau dengan nilai SPT pada lapisan paling atas (kedalaman kurang dari $15 \mathrm{~m}$ ) kurang dari 15. Berdasarkan persyaratan terjadinya likuefaksi salah satunya nilai SPT kurang dari 15 dan tejadi pada tanah jenuh air.

Tabel 2 menujukkan bahwa pada kedalaman 3-14 m terjadi likuefaksi sedangkan Tabel 3 menujukkan bahwa pada kedalaman 4-24 m tanah terlikuefaksi. 


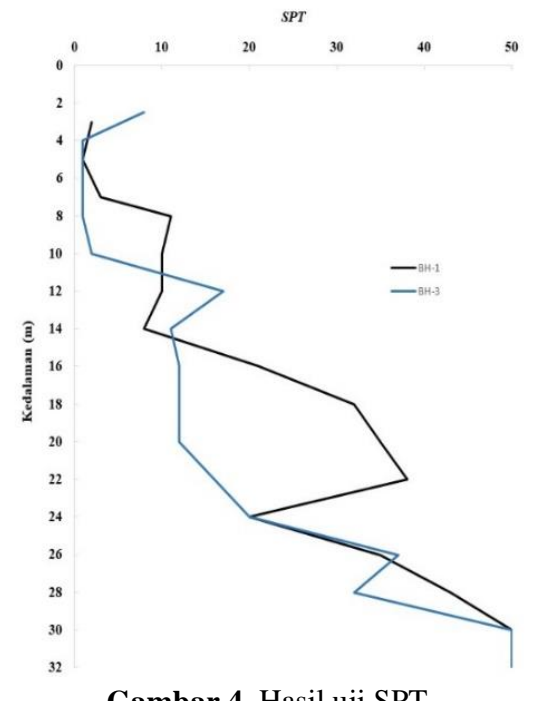

Gambar 4. Hasil uji SPT

Tabel 2. Hasil perhitungan potensi likuefaksi pada titik BH-1

\begin{tabular}{|c|c|c|c|c|c|c|c|c|c|c|c|c|c|c|c|c|c|c|}
\hline $\begin{array}{c}\mathrm{H} \\
(\mathrm{m})\end{array}$ & $\begin{array}{c}\mathrm{N}- \\
\text { value }\end{array}$ & $\begin{array}{l}\text { Jenis } \\
\text { tanah }\end{array}$ & $\mathrm{C}_{\mathrm{E}}$ & $\mathrm{C}_{\mathrm{B}}$ & $\mathrm{C}_{\mathrm{R}}$ & $\mathrm{C}_{\mathrm{S}}$ & $\mathrm{N}_{60}$ & $\left(\mathrm{~N}_{1}\right)_{60}$ & $\left(\mathrm{~N}_{1}\right)_{60 \mathrm{cs}}$ & $\begin{array}{c}\sigma_{\mathrm{vc}} \\
\left(\mathrm{kN} / \mathrm{m}^{2}\right)\end{array}$ & $\begin{array}{c}\sigma_{\mathrm{vc}}^{\prime} \\
\left(\mathrm{kN} / \mathrm{m}^{2}\right)\end{array}$ & $\mathrm{CN}$ & $\mathrm{rd}$ & CSR & $\begin{array}{c}\mathrm{CRR}_{\mathrm{M}} \\
=7,5\end{array}$ & CRR & $\mathrm{FS}_{\text {liq }}$ & Keterangan \\
\hline 3 & 2 & $\mathrm{CH}$ & 1 & 1 & 0,85 & 1 & 1,7 & 2,63 & 8,25 & 47 & 47 & 1,55 & 0,99 & 0,24 & 0,11 & 0,10 & 0,41 & $\mathrm{~L}$ \\
\hline 5 & 1 & $\mathrm{CH}$ & 1 & 1 & 0,95 & 1 & 1,0 & 1,30 & 6,91 & 79 & 59 & 1,36 & 0,98 & 0,31 & 0,10 & 0,09 & 0,28 & $\mathrm{~L}$ \\
\hline 7 & 3 & CL & 1 & 1 & 0,95 & 1 & 2,9 & 3,44 & 9,04 & 111 & 72 & 1,21 & 0,96 & 0,36 & 0,11 & 0,10 & 0,28 & $\mathrm{~L}$ \\
\hline 8 & 11 & $\mathrm{CL}$ & 1 & 1 & 0,95 & 1 & 10,5 & 11,75 & 17,35 & 128 & 78 & 1,12 & 0,96 & 0,37 & 0,18 & 0,16 & 0,42 & $\mathrm{~L}$ \\
\hline 10 & 10 & CL & 1 & 1 & 1,00 & 1 & 10,0 & 10,50 & 16,10 & 160 & 91 & 1,05 & 0,94 & 0,39 & 0,17 & 0,14 & 0,37 & $\mathrm{~L}$ \\
\hline 12 & 10 & CL & 1 & 1 & 1,00 & 1 & 10,0 & 9,86 & 15,46 & 192 & 104 & 0,99 & 0,92 & 0,41 & 0,16 & 0,14 & 0,34 & $\mathrm{~L}$ \\
\hline 14 & 8 & CL & 1 & 1 & 1,00 & 1 & 8,0 & 7,43 & 13,03 & 225 & 117 & 0,93 & 0,90 & 0,41 & 0,14 & 0,12 & 0,29 & $\mathrm{~L}$ \\
\hline 16 & 21 & ML & 1 & 1 & 1,00 & 1 & 21,0 & 18,99 & 24,60 & 257 & 130 & 0,90 & 0,88 & 0,46 & 0,28 & 0,23 & 0,50 & $\mathrm{~L}$ \\
\hline 18 & 32 & ML & 1 & 1 & 1,00 & 1 & 32,0 & 28,52 & 34,12 & 290 & 142 & 0,89 & 0,86 & 0,46 & 0,93 & 0,73 & 1,58 & NL \\
\hline 20 & 35 & ML & 1 & 1 & 1,00 & 1 & 35,0 & 30,47 & 36,08 & 322 & 155 & 0,87 & 0,83 & 0,46 & 1,40 & 1,06 & 2,00 & NL \\
\hline 22 & 38 & ML & 1 & 1 & 1,00 & 1 & 38,0 & 32,46 & 38,06 & 354 & 168 & 0,85 & 0,81 & 0,46 & 2,00 & 1,46 & 2,00 & NL \\
\hline 24 & 20 & ML & 1 & 1 & 1,00 & 1 & 20,0 & 15,57 & 21,17 & 387 & 181 & 0,78 & 0,79 & 0,45 & 0,22 & 0,17 & 0,39 & $\mathrm{~L}$ \\
\hline 26 & 35 & SM & 1 & 1 & 1,00 & 1 & 35,0 & 28,09 & 33,70 & 419 & 193 & 0,80 & 0,77 & 0,44 & 0,86 & 0,62 & 1,40 & NL \\
\hline 28 & 43 & SM & 1 & 1 & 1,00 & 1 & 43,0 & 34,81 & 40,42 & 452 & 206 & 0,81 & 0,75 & 0,44 & 2,00 & 1,36 & 2,00 & NL \\
\hline 30 & 50 & SM & 1 & 1 & 1,00 & 1 & 50,0 & 40,79 & 46,39 & 484 & 219 & 0,82 & 0,73 & 0,43 & 2,00 & 1,33 & 2,00 & NL \\
\hline 32 & 50 & SM & 1 & 1 & 1,00 & 1 & 50,0 & 40,13 & 45,73 & 516 & 232 & 0,80 & 0,72 & 0,43 & 2,00 & 1,30 & 2,00 & NL \\
\hline
\end{tabular}


Tabel 3. Hasil perhitungan potensi likuefaksi pada titik BH-3

\begin{tabular}{|c|c|c|c|c|c|c|c|c|c|c|c|c|c|c|c|c|c|c|}
\hline $\begin{array}{c}\mathrm{H} \\
(\mathrm{m})\end{array}$ & $\begin{array}{c}\mathrm{N}- \\
\text { value }\end{array}$ & $\begin{array}{l}\text { Jenis } \\
\text { tanah }\end{array}$ & $\mathrm{C}_{\mathrm{E}}$ & $\mathrm{C}_{\mathrm{B}}$ & $\mathrm{C}_{\mathrm{R}}$ & $\mathrm{C}_{\mathrm{S}}$ & $\mathrm{N}_{60}$ & $\left(\mathrm{~N}_{1}\right)_{60}$ & $\left(\mathrm{~N}_{1}\right)_{60 \mathrm{cs}}$ & $\begin{array}{c}\sigma_{\mathrm{vc}} \\
\left(\mathrm{kN} / \mathrm{m}^{2}\right)\end{array}$ & $\begin{array}{c}\sigma_{\mathrm{vc}}^{\prime} \\
\left(\mathrm{kN} / \mathrm{m}^{2}\right)\end{array}$ & $\mathrm{CN}$ & $\mathrm{rd}$ & CSR & $\mathrm{CRR}_{\mathrm{M}=7,5}$ & CRR & $\mathrm{FS}_{\text {liq }}$ & Ket \\
\hline 2,5 & 8 & $\mathrm{CH}$ & 1 & 1 & 0.85 & 1 & 6.8 & 10.76 & 16.37 & 38 & 38 & 1.58 & 0.99 & 0.24 & 0.17 & n.a & n.a & $\mathrm{NL}$ \\
\hline 4 & 1 & $\mathrm{CH}$ & 1 & 1 & 0.85 & 1 & 0.9 & 1.26 & 6.88 & 66 & 51 & 1.49 & 0.98 & 0.30 & 0.10 & 0.09 & 0.29 & $\mathrm{~L}$ \\
\hline 6 & 1 & $\mathrm{CL}$ & 1 & 1 & 0.95 & 1 & 1.0 & 1.19 & 6.80 & 103 & 68 & 1.26 & 0.97 & 0.35 & 0.10 & 0.09 & 0.25 & $\mathrm{~L}$ \\
\hline 8 & 1 & $\mathrm{CL}$ & 1 & 1 & 0.95 & 1 & 1.0 & 1.05 & 6.65 & 139 & 85 & 1.10 & 0.96 & 0.37 & 0.10 & 0.08 & 0.22 & $\mathrm{~L}$ \\
\hline 10 & 2 & CL & 1 & 1 & 1.00 & 1 & 2.0 & 1.98 & 7.59 & 176 & 102 & 0.99 & 0.94 & 0.38 & 0.10 & 0.09 & 0.23 & $\mathrm{~L}$ \\
\hline 12 & 17 & CL & 1 & 1 & 1.00 & 1 & 17.0 & 15.82 & 21.42 & 213 & 119 & 0.93 & 0.92 & 0.44 & 0.22 & 0.19 & 0.43 & $\mathrm{~L}$ \\
\hline 14 & 11 & CL & 1 & 1 & 1.00 & 1 & 11.0 & 9.50 & 15.11 & 249 & 137 & 0.86 & 0.90 & 0.39 & 0.16 & 0.13 & 0.33 & $\mathrm{~L}$ \\
\hline 16 & 12 & ML & 1 & 1 & 1.00 & 1 & 12.0 & 9.80 & 15.40 & 286 & 154 & 0.82 & 0.88 & 0.39 & 0.16 & 0.13 & 0.34 & $\mathrm{~L}$ \\
\hline 18 & 12 & ML & 1 & 1 & 1.00 & 1 & 12.0 & 9.29 & 14.89 & 323 & 171 & 0.77 & 0.86 & 0.39 & 0.16 & 0.13 & 0.33 & $\mathrm{~L}$ \\
\hline 20 & 12 & ML & 1 & 1 & 1.00 & 1 & 12.0 & 8.84 & 14.45 & 359 & 188 & 0.74 & 0.83 & 0.38 & 0.15 & 0.12 & 0.32 & $\mathrm{~L}$ \\
\hline 22 & 16 & ML & 1 & 1 & 1.00 & 1 & 16.0 & 11.51 & 17.11 & 396 & 205 & 0.72 & 0.81 & 0.42 & 0.17 & 0.14 & 0.33 & $\mathrm{~L}$ \\
\hline 24 & 20 & ML & 1 & 1 & 1.00 & 1 & 20.0 & 14.11 & 19.71 & 433 & 222 & 0.71 & 0.79 & 0.41 & 0.20 & 0.16 & 0.38 & $\mathrm{~L}$ \\
\hline 26 & 37 & SM & 1 & 1 & 1.00 & 1 & 37.0 & 27.57 & 33.17 & 470 & 239 & 0.75 & 0.77 & 0.40 & 0.78 & 0.53 & 1.32 & NL \\
\hline 28 & 32 & SM & 1 & 1 & 1.00 & 1 & 32.0 & 22.54 & 28.15 & 506 & 256 & 0.70 & 0.75 & 0.40 & 0.39 & 0.28 & 0.70 & $\mathrm{~L}$ \\
\hline 30 & 50 & SM & 1 & 1 & 1.00 & 1 & 50.0 & 37.95 & 43.55 & 543 & 273 & 0.76 & 0.73 & 0.39 & 2.00 & 1.21 & 2.00 & NL \\
\hline 32 & 50 & SM & 1 & 1 & 1.00 & 1 & 50.0 & 37.13 & 42.73 & 580 & 290 & 0.74 & 0.72 & 0.38 & 2.00 & 1.18 & 2.00 & $\mathrm{NL}$ \\
\hline
\end{tabular}

\section{dengan,}

\begin{tabular}{|c|c|}
\hline$N_{\text {-value }}$ & : nilai SPT terukur \\
\hline$C_{E}$ & : faktor koreksi energi hammer \\
\hline$C_{B}$ & : faktor koreksi diameter bore hole \\
\hline$C_{R}$ & : faktor koreksi panjang \\
\hline$C_{S}$ & : faktor koreksi sampel \\
\hline$\left(N_{l}\right)_{60}$ & : $\quad$ nilai $S P T$ terkoreksi \\
\hline$\left(N_{l}\right)_{60 c s}$ & : tahanan tegangan vertikal efektif yang dikoreksi \\
\hline$C_{N}$ & : faktor berdasarkan overburden stress \\
\hline$r d$ & : faktor reduksi stres suatu kedalaman \\
\hline$C S R$ & : Cyclic Stress Ratio \\
\hline$\sigma_{v c}$ & : tegangan total \\
\hline$\sigma_{v c}^{\prime}$ & : tegangan efektif overburden rata-rata eksisting \\
\hline$C R R$ & : Cyclic Resistance Ratio tanah \\
\hline
\end{tabular}

CRR $R_{M=7,5} \quad$ : $\quad$ Cyclic Resistance Ratio bedasarkan kekuatan gempa $\mathrm{M}_{7,5}$ $F S_{\text {liq }} \quad$ : faktor aman terhadap potensi likuefaksi

$N L \quad:$ non-likuefaksi, dimana $F S_{l i q}>1$

$L \quad$ : Terlikuefaksi, dimana $F S_{l i q}<1$

Berdasarkan hasil rekapitulasi perhitungan pada

Tabel 2 dan Tabel 3 maka dapat digambarkan hasilnya dalam bentuk grafik hubungan CSR, CRR, FS $S_{\text {liq }}$ terhadap kedalaman. 


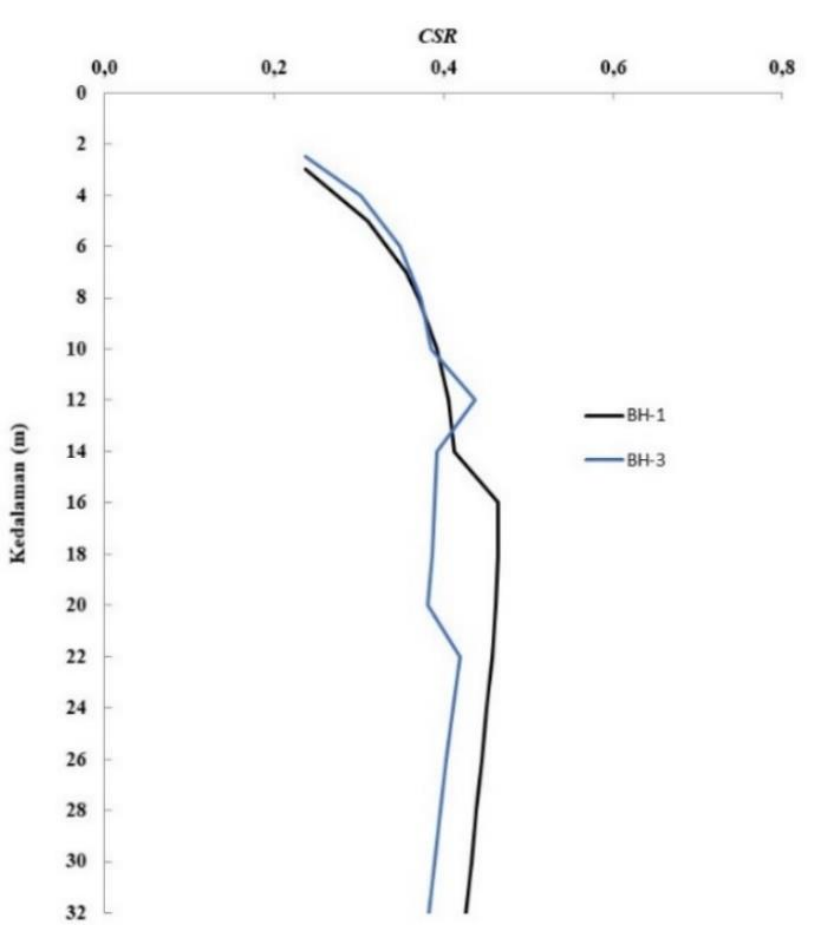

(a)

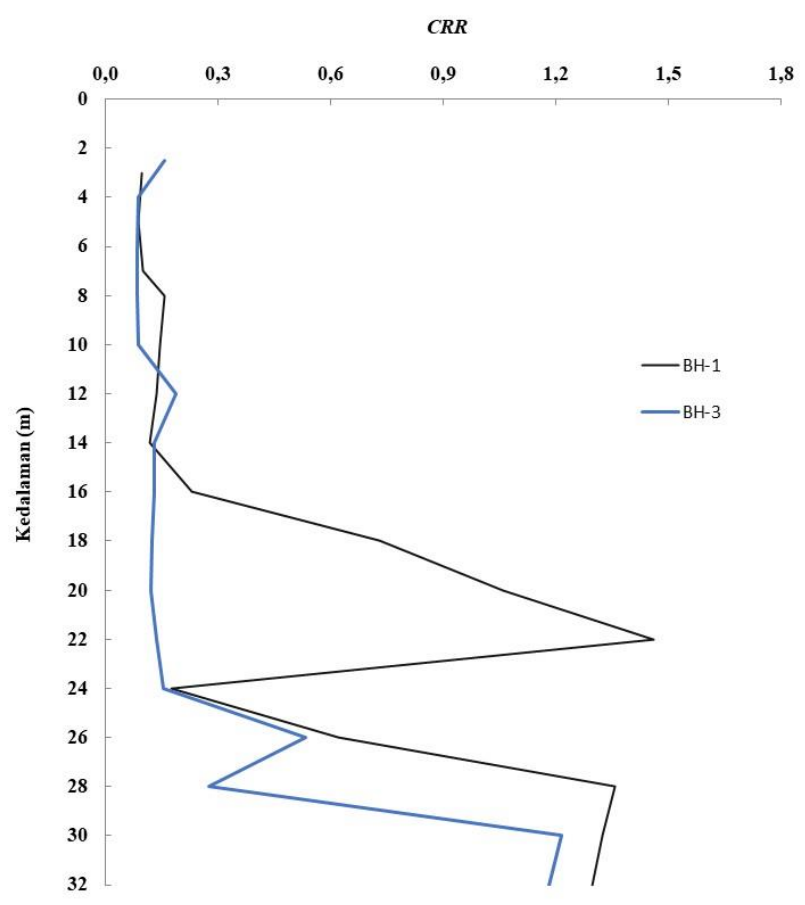

(b)

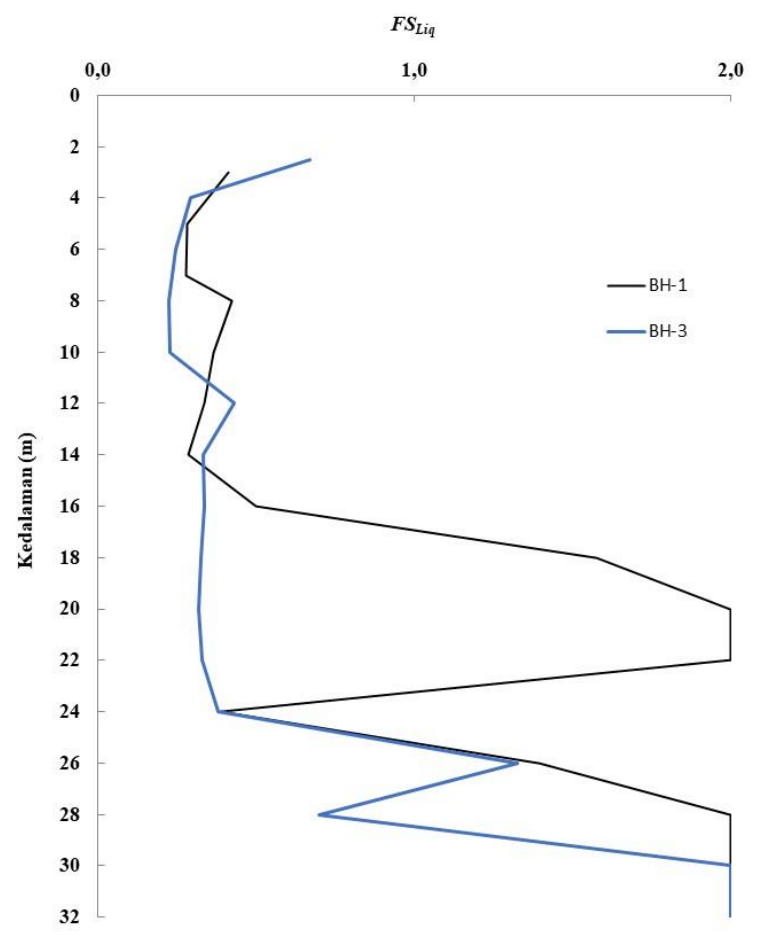

(c)

Gambar 5. Grafik hubungan (a) CSR dengan kedalaman (b) $C R R$ dengan kedalaman (c) $F S_{\text {liq }}$ dengan kedalaman

Gambar 5 menunjukkan bahwa pada kedua titik bore hole memiliki rata-rata nilai $C R R<C S R$. Pada kedua titik bore hole dengan kedalaman tertentu yang memiliki nilai $F S_{\text {liq }}$ $<1$ maka lokasi coal shelter berpotensi terjadi likuefaksi sehingga pada area tersebut perlu diberikan perbaikan tanah dengan stone column. Pada titik BH-1 dan BH-3 berpotensi likuefaksi dengan beberapa variasi kedalaman. Pada titik BH-1 terjadi di kedalaman 3-16 m dan pada titik BH-3 potensi likuefaksi terjadi pada kedalaman 4-24 m. Lapisan yang paling tebal mengalami potensi likuefaksi ada pada titik BH-3 dengan kedalaman $24 \mathrm{~m}$.

Untuk mengetahui tingkat risiko likuefaksi pada area coal shelter dianalisis menggunakan Persamaan (6), dari hasil analisis pada kedua titik bore hole (

Tabel 4) diperoleh nilai rata-rata tingkat risiko likuefaksi pada kedalaman kurang dari 10 m tinggi sedangkan untuk kedalaman lebih dari $10 \mathrm{~m}$ tingkat risiko likuefaksi menjadi rendah dan pada lapisan tanah keras tingkat risiko likuefaksi sangat rendah.

Tabel 4. Hasil analisis Liquefaction Potential Index (LPI) [7]

\begin{tabular}{cccc}
\hline Titik & Kedalaman $(\mathrm{m})$ & $\begin{array}{c}\text { Indeks Potensi } \\
\text { Likuefaksi }(L P I)\end{array}$ & $\begin{array}{c}\text { Klasifikasi } \\
\text { potensi likuefaksi }\end{array}$ \\
\hline BH- & 5 & 5,39 & Tinggi \\
1 & 14 & 2,14 & Rendah \\
& 22 & 0 & Sangat rendah \\
BH- & 4 & 5,66 & Tinggi \\
3 & 14 & 2 & Rendah \\
& 22 & 0 & Sangat rendah \\
\hline
\end{tabular}




\subsection{Metode Perbaikan dengan Stone Column}

Persyaratan umum dalam mendesain perbaikan tanah dengan stone column yaitu minimal kedalaman column 8-10 m. Apabila lapisan likuefaksi terjadi pada kedalaman lebih dari $10 \mathrm{~m}$ maka disarankan desain stone column sampai pada lapisan ujung yang berpotensi terlikuefaksi.

Pada penelitian ini, desain stone column pada kedua titik bore hole menggunakan tipe floating type improvement, dimana ujung dari kolom berada diantara lapisan tanah lunak. Namun ujung dari kolom sudah berapa pada lapisan tanah yang memiliki tingkat risiko likuefaksi rendah.

Pola pemasangan stone column menggunakan pola segitiga. Berdasarkan kajian teori, pola segitiga lebih efektif dan gaya yang bekerja lebih stabil serta penurunan tanah akan lebih seragam. Dimensi stone column; diameter (D) $80 \mathrm{~cm}$, jarak antar stone column $(S) 200 \mathrm{~cm}$ dan tinggi column $(H) 10 \mathrm{~m}$.

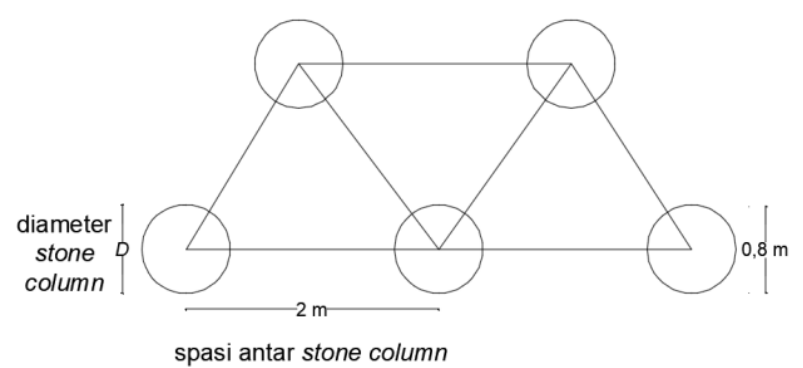

Gambar 6. Konfigurasi stone column

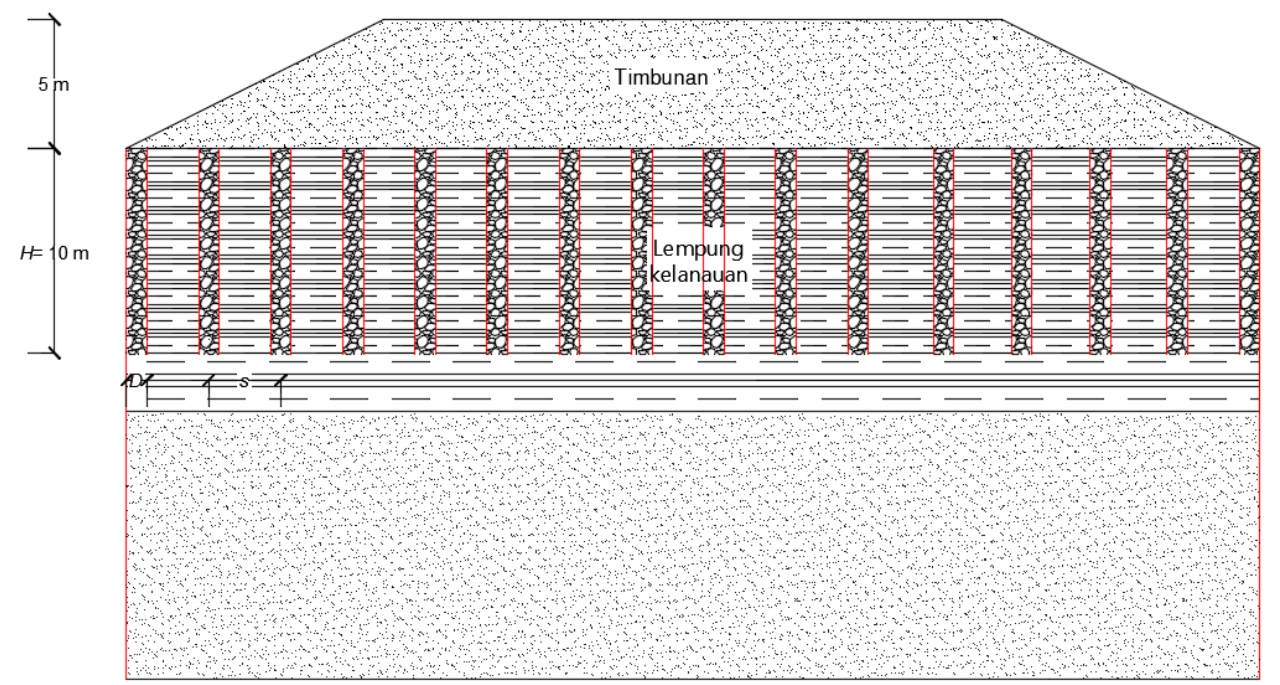

*D: diameter column

S: jarak antar column

Gambar 7. Tampak depan ilustrasi pemasangan stone column

Analisis perbaikan dengan stone column menggunakan Plaxis pada kedua titik bore hole, dimana input parameternya seperti Tabel 5.

Tabel 5. Input parameter Plaxis Parameter stone column yang digunakan

\begin{tabular}{cccccc}
\hline $\begin{array}{c}D \\
(\mathrm{~cm})\end{array}$ & $\begin{array}{c}S \\
(\mathrm{~cm})\end{array}$ & $\begin{array}{c}H \\
(\mathrm{~m})\end{array}$ & $\begin{array}{c}\gamma_{\text {sat }} \\
\left(\mathrm{kN} / \mathrm{m}^{3}\right)\end{array}$ & $\begin{array}{c}E_{s c} \\
\left(\mathrm{kN} / \mathrm{m}^{2}\right)\end{array}$ & $k_{v}$ \\
80 & 200 & 10 & 19 & 58000 & 1 \\
\hline
\end{tabular}

Hasil output dari Plaxis diperoleh bahwa nilai faktor aman (FS) pada titik BH-1 yaitu 2,89, pada titik BH-3 FS menjadi 2,65. Berdasarkan persyaratan desain, untuk nilai faktor aman lebih dari 1,5 maka konstruksi tersebut dapat mengurangi potensi terjadinya likuefaksi dan mampu meningkatkan nilai faktor keamanan terhadap potensi likuefaksi di lokasi coal shelter.

\section{Simpulan}

Berdasarkan hasil interpretasi tanah pada lokasi penelitian coal shelter PLTU, pada lapisan atas didominasi tanah lempung kelanauan dengan nilai SPT kurang dari 15 dan lapisan bawah dominan tanah pasir kelanauan yang padat dengan nilai SPT lebih dari 50. Berdasarkan hasil perhitungan faktor keamanan terhadap potensi likuefaksi $\left(F S_{\text {liq }}\right)$ dapat disimpulkan bahwa semua titik memiliki potensi likuefaksi di kedalaman tertentu. Pada titik BH-1 potensi likuefaksi berada pada kedalaman 3-16 m dan pada titik BH-3 potensi likuefaksi terjadi pada kedalaman 4-24 m. Dengan demikian lokasi coal shelter 
perlu dilakukan perbaikan untuk mengurangi potensi likuefaksi di lokasi tersebut yaitu dengan pemasangan stone column. Pemasangan stone coloumn dapat meningkatkan nilai faktor keamanan terhadap potensi likuefaksi di lokasi coal shelter. Nilai faktor aman setelah dipasang stone column pada titik BH-1 FS 2,89, pada titik BH-3 FS menjadi 2,65.

\section{Daftar Rujukan}

[1] E. Soebowo, A. Tohari, and D. Sarah, "Potensi likuifaksi akibat gempabumi berdasarkan data CPT dan N-Spt di Daerah Patalan Bantul, Yogyakarta," Ris. Geol. dan Pertamb., vol. 2, no. 2, pp. 85-97, 2009.

[2] M. Otsubo, I. Towhata, T. Hayashida, B. Liu, and S. Goto, "Shaking table tests on liquefaction mitigation of embedded lifelines by backfilling with recycled materials," Soils Found., vol. 56, no. 3, pp. 365-378, 2016, doi: 10.1016/j.sandf.2016.04.004.

[3] S. Toprak and T. L. Holzer, "Liquefaction Potential Index: Field assessment," J. Geotech. Geoenvironmental Eng., vol. 129, no. 4, pp. 315322, 2003, doi: 10.1061/(asce) 1090 0241(2003)129:4(315).

[4] H. B. Seed and I. M. Idriss, "Simplified procedure for evaluating soil liquefaction potential," J. Soil Mech. Found., vol. 97, no. 9, 1971, doi: https://doi.org/10.1061/JSFEAQ.0001662.

[5] M. Mokhtari and B. Kalantar, "Soft soil stabilization using stone columns-a review," Electron. J. Geotech. Eng., vol. 17, pp. 1459-1466, 2012.

[6] T. Iwasaki, T. Arakawa, and K. I. Tokida,
"Simplified procedures for assessing soil liquefaction during earthquakes," Soil Dyn. Earthq. Eng., vol. 3, no. 1, pp. 49-58, 1984, doi: 10.1016/0261-7277(84)90027-5.

[7] T. Iwasaki, K. Tokida, and F. Tatsuoka, "Soil liquefaction potential evaluation with use of the simplified procedure," First Int. Conf. Recent Adv. Geotech. Earthq. Eng. Soil Dyn., pp. 209-214, 1981.

[8] A. Jalil, T. F. Fathani, I. Satyarno, and W. Wilopo, "A study on the liquefaction potential in Banda Aceh city after the 2004 Sumatera earthquake," Int. J. GEOMATE, vol. 18 , no. 65 , pp. 147-155, 2020, doi: $10.21660 / 2020.65 .94557$.

[9] I. M. Idriss and R. W. Boulanger, "Soil liquefaction during earthquakes," Earthq. Eng. Res. Inst., 2008.

[10] M. A. Nisa, I. Satyarno, and H. C. Hardiyatmo, "Perancangan fondasi gedung Temporary Evacuation Shelter (TES) tsunami dan gempa," INERSIA INformasi dan Ekspose Has. Ris. Tek. SIpil dan Arsit., vol. 16, no. 2, pp. 117-129, 2020, doi: 10.21831/inersia.v16i2.36898.

[11] T. L. Youd and I. M. Idriss, "Liquefaction resistance of soils: Summary report from the 1996 NCEER and 1998 NCEER/NSF workshops on evaluation of liquefaction resistance of soils," $J$. Geotech. Geoenvironmental Eng., vol. 127, no. 10, pp. 817-833, 2001.

[12] FHWA, "Design and Construction Stone Columns Vol 1,” no. December 1983, 1983.

[13] B. McCabe, J. McNeill, and J. Black, "Ground improvement using the vibro-stone column technique," Jt. Meet. Eng. Irel. ..., no. January 2015, pp. 1-12, 2007. 